\title{
KEPEMIMPINAN KEPALA SEKOLAH DALAM PENCEGAHAN COVID 19 DI SD/MI KOTA MEDAN
}

\author{
Amiruddin Siahaan, Toni Nasution, Khairul Anwar \\ Universitas Islam Negeri Sumatera Utara Medan, \\ amiruddinsiahaan@uinsu.ac.id.toninasution@uinsu.ac.id,khairulanwar@uinsu.ac.id
}

\begin{abstract}
The Corona virus, or Covid-19, outbreak in China has spread to more than 121 countries. This has a knock-on effect on all aspects of life, including education. On March 2, 2020, Indonesia announced the confirmation of the Corona Virus. As a result, the government issued a fatwa to implement online education through the Ministry of Education and Culture.The findings of this study seek to determine how the principal's leadership carries out its responsibilities in dealing with and preventing the transmission of covid 19. The research was conducted at SD Negeri 060855 and MIN 4 Medan. The qualitative descriptive method was used in this study. Data was gathered through interviews, observations (triangulation), and a review of the literature. Teachers and employees from SD Negeri 060855 and MIN 4 Medan were interviewed. This interviewee or informant was chosen based on a number of criteria, including teachers and school employees who were directly involved in COVID-19 prevention by the principal.A triangulation technique is used to ensure the accuracy of the data. To produce keywords or a conclusion, data reduction, data presentation, and data coding are used as data analysis techniques. The findings of this study show that: First, the principal implements a learning from home policy. Second, put together a Task Force team. Third, in order to solve problems, it is necessary to collaborate and establish communication.
\end{abstract}

Keywords: Leadership; Headmaster; Covid-19; SD/MI.

Abstrak

Merebaknya virus Corona atau Covid-19 di China telah menyebar ke lebih dari 121 negara. Hal inı menyebabkan segala aspek dalam kehidupan terganggu, termasuk sektor pendidikan.Indonesia sendiri mengumumkan terkonfirmasi Virus Corona pada 2 Maret 2020. Sehingga pemerintah mengeluarkan fatwa melalui Kementrian Pendidikan dan Kebudayaan untuk melaksanakan pendidikan secara daring. Hasil penelitian ini bertujuan untuk mengetahui bagaimana kepemimpinan kepala sekolah menjalankan tugasnya dalam penanganan mencegah penularan covid 19. Subjek penelitian dilakukan di SD Negeri 060855 dan MIN 4 Kota Medan. Metode yang digunakan dalam penelitian adalah metode deskriptif kualitatif. Pengumpulan datanya dilakukan dengan wawancara, observasi, (trianggulasi) dan studi pustaka. Wawancara dilakukan dengan guru dan karyawan SD Negeri 060855 dan MIN 4 Kota Medan. Partisipan atau informan wawancara ini dipilih melalui beberapa kriteria, antara lain guru dan pegawai sekolah yang terlibat langsung oleh kepala sekolah dalam pencegahan covid-19. Keabsahan data yang digunakan adalah teknik triangulasi. Teknik analisis data yang digunakan adalah reduksi data, penyajian data, dan pengcodingan data sehingga menghasilkan kata kunci atau sebuah kesimpulan. Hasil penelitian ini menunjukkan bahwasanya; Pertama, kepala sekolah memberikan kebijakan belajar dari rumah. Kedua, membentuk tim Gugus Tugas. Ketiga, bekerjasama dan menjalin komunikasi dalam memecahkan masalah.

Kata Kunci: Kepemimpinan; Kepala Sekolah; Covid-19; SD/MI. 


\section{Amiruddin S, Toni N, Khairul Anwar}

\section{A. Pendahuluan}

Merebaknya virus corona atau covid-19 di China telah menyebar ke lebih dari 121

Negara. Virus ini pertama kali muncul di Wuhan, China, pada Desember 2019. Meski angka kesembuhan penyakit ini lebih dari setengah jumlah kasus yang terinfeksi, virus corona jenis baru yang pertama kali ditemukan di Wuhan telah menewaskan lebih dari 4.000 orang. Pada Rabu (11/3/2020), Badan Kesehatan Dunia (WHO) menyatakan virus corona jenis baru penyebab Covid-19 telah menjadi pandemi global. ${ }^{1}$

Virus ini mengganggu saluran pernapasan seperti flu biasa. Gejalanya adalah batuk, pilek, demam, sakit kepala, dan sesak napas. Virus ini tidak terlalu berbahaya jika menginfeksi orang yang berusia di bawah 40 tahun dan memiliki daya tahan tubuh yang sangat baik, tetapi pada orang dewasa yang lebih tua dan penderita yang memiliki penyakit bawaan seperti jantung, hipertensi, gula, paru-paru, maka akibatnya bisa fatal, yakni , kematian. Penularan virus COVID-19 ini bisa melalui droplet laring yang terinfeksi virus saat ia batuk, bersin, meludah, atau berbicara. Presiden Joko Widodo mengumumkan dua WNI positif terinfeksi COVID-19 pada 2 Maret 2020. Sejak saat itu, pemerintah melakukan berbagai upaya pencegahan. Pasien positif, orang dalam pengawasan (ODP) dan pasien dalam pengawasan (PDP) terus bertambah setiap harinya ${ }^{2}$

Pemerintah pusat dan daerah mengimbau masyarakat untuk mengurangi aktivitas di luar ruangan, termasuk Kota Medan. Hal itu dikarenakan penularan virus sangat mudah dan cepat melalui droplet orang yang positif ketika dia batuk, bersin, meludah, atau berbicara. Semua lini terkena dampak pandemi ini, termasuk aspek pendidikan di Medan. Banyaknya mahasiswa dan perantau di wilayah Medan mendorong pemerintah daerah dan pihak terkait untuk mengambil kebijakan darurat. Suatu kebijakan pendidikan yang diambil, disosialisasikan kepada kepemimpinan esensial yaitu kepala sekolah. Peran kepemimpinan

1 La Hewi and Linda Asnawati, "Strategi Pendidik Anak Usia Dini Era Covid-19 Dalam Menumbuhkan Kemampuan Berfikir Logis," Jurnal Obsesi : Jurnal Pendidikan Anak Usia Dini 5, no. 1 (2020): 158, https://doi.org/10.31004/obsesi.v5i1.530. Lihat juga Malcolm Brown et al., "Framework_Guide_V1_002_Harward," Journal of Professional Capital and Community 28, no. 2 (2020): 2340-50, http://oro.open.ac.uk/59302/7/Thesis Final Papathoma_03.03.2019.pdf

${ }^{2}$ Bisyri Abdul Karim, "Pendidikan Perguruan Tinggi Era 4.0 Dalam Pandemi Covid-19

(Refleksi Sosiologis)," Education and Learning Journal 1, no. 2 (2020): 102, https://doi.org/10.33096/eljour.v1i2.54. 
kepala sekolah sangat diperlukan dalam pelaksanaan kebijakan di masa darurat COVID-19 ini. Di masa pandemi ini, kepala dinas merupakan faktor utama yang bisa diselesaikan dengan permasalahan yang muncul.

Berdasarkan keterangan resminya, alternatif yang ditempuh pemerintah Indonesia melalui Kementerian Pendidikan dan Kebudayaan siap dengan segala skenario, termasuk melaksanakan kerjasama untuk mendorong pembelajaran online bagi siswa. Menyusul surat edaran Kementerian Pendidikan dan Kebudayaan Nomor 36962/MPK. A/HK/2020 terkait pembelajaran online dan kerja dari rumah untuk mencegah penyebaran virus Corona (COVID-19). Kebijakan tersebut merupakan upaya agar siswa tetap di rumah. Kementerian Pendidikan Kebudayaan dan Teknologi (Kemendikristek) menyiapkan sejumlah dukungan untuk mempercepat proses tersebut. Kemendikbudristek mengembangkan aplikasi pembelajaran jarak jauh berbasis portal dan android serta rumah belajar lainnya.

Bank Dunia mengatakan bahwa pandemi Covid-19 kini mengancam dan berpotensi memperburuk hasil pendidikan. Pandemi telah berdampak signifikan pada pendidikan dengan menutup sekolah hampir di mana-mana di dunia. Namun, adalah mungkin untuk mengatasi guncangan ini dan mengubah krisis menjadi peluang. Langkah pertama adalah berhasil mengatasi penutupan sekolah dengan melindungi kesehatan dan keselamatan dan mencegah siswa kehilangan pembelajaran menggunakan pembelajaran jarak jauh. Pada saat yang sama, negara bagian perlu mulai merencanakan pembukaan kembali sekolah. Itu berarti mencegah putus sekolah, memastikan kondisi sekolah yang sehat, dan menggunakan teknik baru untuk mendorong pemulihan pembelajaran yang cepat di bidang-bidang penting setelah siswa kembali ke sekolah. ${ }^{3}$

Situasi Pandemi dimana peran penting seorang kepala sekolah adalah untuk tetap menjalankan kepemimpinannya dengan baik di saat krisis seperti ini. Kepala sekolah dituntut untuk menerapkan "manajemen krisis", yaitu proses mempersiapkan dan mengelola situasi darurat atau tidak terduga yang mempengaruhi siswa, guru, staf, dan pemangku kepentingan. Kepemimpinan merupakan komponen penting dari Public Relations (PR). Berbeda dengan manajemen risiko, yang mengharuskan prinsipal untuk menilai potensi ancaman dan

\footnotetext{
${ }^{3}$ Ulin Nuskhi Muti'ah, “, Teaching Collaborations in Elementary Schools: Teacher's Understanding, Strategies, and Obstacles," Ta'dib: JURNAL PENDIDIKAN GURU MI 8, no. 1 (2021): 1-15, http://syekhnurjati.ac.id/jurnal/index.php/ibtida.
} 


\section{Amiruddin S, Toni N, Khairul Anwar}

menemukan cara terbaik untuk menghindari ancaman tersebut. Dalam manajemen krisis, ancaman ini sudah terjadi dan harus dihadapi. ${ }^{4}$

Page | 137

Kesiapan sekolah untuk melaksanakan pembelajaran online dengan memanfaatkan teknologi sebagai media pembelajaran online tidak mudah dilaksanakan karena banyaknya kendala yang menghambat untuk mendapatkan pembelajaran berjalan efektif. Masalah ekonomi menjadi kendala yang muncul pada siswa SDN 060855 karena pembelajaran online menggunakan internet membutuhkan uang untuk membeli paket data. ${ }^{5}$ Masalah lain yang muncul adalah sulitnya jaringan internet; tidak semua sekolah terkoneksi dengan internet, sehingga guru yang menggunakan jaringan internet kurang stabil. ${ }^{6}$

Sekolah sebagai lembaga pendidikan memiliki tanggung jawab untuk memastikan kegiatan pembelajaran berjalan dengan aman. Adanya COVID-19 mengharuskan sekolah mengambil kebijakan untuk menghadapi atau mencegah penularan virus COVID-19. Sehingga siswa tetap dapat melaksanakan pembelajarannya dengan baik tanpa merasa cemas dan cemas. Kepala sekolah sebagai pengambil keputusan memiliki peran yang signifikan dalam penanganan virus Covid-19 demi keselamatan siswa dan kelangsungan pembelajaran. ${ }^{7}$

Kebijakan adalah aturan tertulis yang merupakan keputusan formal organisasi, yang mengikat, mengatur perilaku untuk menciptakan sistem nilai baru dalam masyarakat. Kebijakan tersebut akan menjadi acuan utama anggota organisasi atau anggota masyarakat dalam berperilaku. Sedangkan menurut PBB, sebagaimana dikutip Solichin, kebijakan adalah pedoman tindakan. Pedoman tersebut bisa sangat sederhana atau berkelompok, umum atau khusus, luas atau sempit, tidak jelas atau jelas, longgar atau terperinci, kualitatif atau

${ }^{4}$ Sri Wahyuningtyas Leonard Natalia Tri Astuti, "Developing MATMINO (Domino Mathematics) Learning Media in Grade 7 Algebra Material," Jurnal Ilmiah Pendidikan MIPA 11, no. 01 (2021): 1-14, https://journal.lppmunindra.ac.id/index.php/Formatif/index.

${ }^{5}$ Hasil Wawancara dengan orangtua Murid SD 060855, Pada tanggal 03 Juni 2021, pukul. 09.03.

${ }^{6}$ Hasil Observasi di MIN 4KOTA MEDAN, pada tanggal, 05 Juni 2021, pukul.07.39.

${ }^{7}$ Wandika Wita Susilowati and Suyatno Suyatno, "Teacher Competence in Implementing Higher-Order Thinking Skills Oriented Learning in Elementary Schools," Premiere Educandum: Jurnal Pendidikan Dasar Dan Pembelajaran 11, no. 1 (2021): 1, https://doi.org/10.25273/pe.v11i1.7762. 
kuantitatif, publik atau pribadi. ${ }^{8}$ Dalam pengertian ini, kebijakan dapat berupa deklarasi kode tindakan yang diperlukan, tindakan tertentu, program tentang kegiatan tertentu, atau rencana.

Kepala sekolah pada hakikatnya adalah seorang perencana, penyelenggara, pemimpin, dan pengontrol. Keberadaan kepala sekolah diperlukan untuk mencapai suatu tujuan yang telah ditetapkan dimana dalam organisasi yang dipimpinnya mengembangkan berbagai ilmu pengetahuan dan organisasi yang menjadi wadah untuk membina dan mengembangkan karir sumber daya manusia. ${ }^{9}$ Suatu organisasi atau lembaga membutuhkan seorang pemimpin untuk menjalankan manajemen guna mencapai tujuannya. ${ }^{10}$ Dalam dunia pendidikan, sekolah membutuhkan seorang pemimpin untuk mengelola kemampuan sekolah agar berjalan dengan baik. Sebagai pemimpin sekolah, kepala sekolah harus memiliki jiwa kepemimpinan yang baik untuk mencapai tujuan pendidikan sekolah secara efektif dan efisien.

Kepala sekolah memiliki peran vital dalam memimpin, merencanakan kebijakan baru pada masa tanggap darurat, menggorganisir seluruh bawahannya, mendistribusikan tugas, dan melaksanakan tugas sesuai rencana dan seluruh warga sekolah. Kepala sekolah juga harus mengontrol pelaksanaan kebijakan baru agar dapat dilaksanakan dengan benar dan mencapai tujuan yang telah direncanakan. Di masa pandemi ini, kepala sekolah harus dapat membagi kepemimpinannya dengan staf pengajar dan pegawai sesuai dengan kemampuannya masingmasing, menjalin hubungan interpersonal, mengembangkan prinsip keadilan dan tanggung jawab, serta mampu bekerja dalam tim, sehingga kebijakan baru pada saat tanggap darurat dapat dilaksanakan dengan lancar dan tujuan pendidikan dapat tercapai.

Dengan demikian peneliti memilih sekolah berstandar Negeri dan memiliki fasilitas ataupun sarana yang sesuai kebutuhan anak usia dasar di kota Medan. Hal inilah yang menjadikan penulis memilih SD Negeri 060855 dan MIN 4 Kota Medan. Penelitian ini

${ }^{8}$ Hurry Mega Insani Lilik Kustiyah Cesilia Meti Dwiriani Ayu Mutiara Santanu, "Nutrition Education on Sedentary Activity for Adolescent," Jurnal Pendidikan Jasmani Dan Olahraga. 06, no. 01 (2021): 19, https://ejournal.upi.edu/index.php/penjas/article/view/6-1-01.

${ }^{9}$ Ridwan Daud Mahande, Fitrah Asma Darmawan, and Jasruddin Daud Malago, "Metacognitive Skill Assessment Model through the Blended Learning Management System in Vocational Education," Jurnal Pendidikan Vokasi 11, no. 1 (2021): 1-13, https://doi.org/10.21831/jpv.v11i1.36912.

${ }^{10}$ Ida Kaniawati et al., "Implementation of Interactive Conceptual Instruction (ICI) With Computer Simulation: Impact of Students' Misconceptions on Momentum and Impulse Material," Jurnal Ilmiah Pendidikan Fisika Al-Biruni $10, \quad$ no. $1 \quad$ (2021): $1-17$, https://doi.org/10.24042/jipfalbiruni.v10i1.8375. 


\section{Amiruddin S, Toni N, Khairul Anwar}

bertujuan untuk mengetahui bagaimana manajemen kepala sekolah dalam menangani pencegahan penularan Covid-19 di lingkungan sekolah sehingga kesehatan dan keselamatan warga sekolah dapat terjaga. Penelitian ini dilakukan di SD/MI Kota Medan. SD/MI yang

Page | 139 menjadi objek penelitian peneliti adalah milik pemerintah atau berstatus SD/MI Negeri di Kota Medan Sumatera Utara. Hal inilah yang menjadi daya tarik peneliti dalam meneliti kepemimpinan kepala sekolah di SD/MI yang "berstatus Negeri” dalam mengelola pada masa pandemic covid 19.

\section{B. Metode Penelitian}

Penelitian ini menggunakan pendekatan inkuiri naratif untuk menyelidiki keyakinan dan pengalaman guru terhadap pembelajaran berbasis web. Penelitian naratif adalah desain penelitian di mana mendongeng digunakan sebagai data atau sarana untuk analisis data dan temuan. ${ }^{11}$ Dalam penelitian ini, cerita yang diperoleh dari partisipan digunakan sebagai data utama. Partisipan penelitian ini dipilih secara purposive berdasarkan tujuan penelitian.

Partisipan merupakan guru yang telah menggunakan pembelajaran berbasis web untuk proses belajar mengajar selama 1 tahun. Hal inilah yang menjadi alasan peneliti. Partisipan adalah karakter utama dalam setiap inkuiri naratif. Kajian ini akan memuat pengalaman hidup partisipan mengenai keyakinan dan pengalamannya terhadap pembelajaran berbasis web yang direpresentasikan sebagai laporan. ${ }^{12}$

Untuk memperoleh data, peneliti melakukan wawancara semi terstruktur dan analisis dokumen. Peneliti mengambil data dari partisipan. Desain wawancara diadopsi dari teori keyakinan dari Richard dan Lockhart. ${ }^{13}$ Ada 20 pertanyaan yang terdiri dari empat aspek keyakinan guru. Kemudian, peneliti merekam dan menyalin wawancara dengan penuh perhatian untuk mendapatkan data yang diverifikasi.

Penelitian ini, data yang telah terkumpul diberi kode dan dianalisis menggunakan Analisis Tematik Studi Kasus Tunggal. Model analisis tematik diusulkan yang terdiri dari studi kasus tunggal dan studi kasus ganda. ${ }^{14}$ Untuk penelitian ini, peneliti menggunakan studi

${ }^{11}$ Meleong. Lexy. J, Metode Penelitian Kualitatif, (Bandung: PT Remaja Rosdakarya)

12 Sugiyono., Metode Penelitian Kuantitatif, Kualitatif, Dan R\&D, (Bandung: Alfabeta, 2014).

13 A. Furhan, Pengantar Metode Penelitian Kualitatif, (Surabaya: Usaha Nasional, n.d.).

${ }^{14}$ Lexy. J, Metode Penelitian Kualitatif. hlm 33 
kasus tunggal untuk menganalisis data dari peserta individu. Selain itu, mengusulkan tiga kegiatan utama dalam analisis tematik. ${ }^{15}$ Pertama, berulang kali membaca data. Kedua, mengkode dan mengkategorikan ekstrak data dan yang terakhir mengenali judul tematik. Proses analisis data dimulai dengan mendengarkan secara seksama rekaman wawancara partisipan. Setelah mendengarkan beberapa kali, wawancara itu dibuat transkrip. Data dibaca berulang-ulang untuk mendapatkan pemahaman yang lebih mendalam. Kemudian data dianalisis dan dikategorikan berdasarkan tema. Selanjutnya untuk mendapatkan kepercayaan, peneliti juga melakukan triangulasi metode. Peneliti juga mendapatkan data dengan wawancara dan analisis dokumen. Itu termasuk dalam triangulasi metode. Di sisi lain, member checking adalah proses di mana peneliti meminta satu atau lebih peserta untuk memeriksa keakuratan akun. Jadi, peneliti bertanya kepada peserta setelah menyalin wawancara; apakah transkripsi jawaban partisipan benar atau tidak. Penelitian ini menggunakan metode deskriptif kualitatif dengan model studi kasus.

Metodologi Kualitatif Deskriptif adalah prosedur penelitian yang menghasilkan data deskriptif dalam kata-kata tertulis atau lisan dari orang-orang dan perilaku yang dapat diamati. Pendekatan ini mengarah pada latar belakang individu Moelong yang holistik. ${ }^{16}$ Maka dalam penelitian ini, pendekatan studi kasus akan digunakan untuk mengungkap peran kepala sekolah dalam pencegahan penularan virus Corona (COVID-19) di SD/MI Negeri Kota Medan. Para peneliti menyelidiki secara menyeluruh dan hati-hati program, peristiwa, kegiatan, dan proses sekelompok individu. Kasus dibatasi oleh waktu dan kegiatan, dan peneliti mengumpulkan informasi secara lengkap dengan menggunakan metode pengumpulan data (wawancara, observasi, dokumen) berdasarkan waktu yang ditentukan.

Peneliti mengeksplorasi fenomena deskriptif Kualitatif. ${ }^{17}$ Penelitian ini bertujuan untuk mengkaji masalah dan memperoleh makna yang lebih mendalam sesuai dengan kajian masalah. Pertimbangan mendasar yang digunakan dalam jenis ini adalah kasus-kasus tersebut

${ }^{15}$ Sugiyono., Metode Penelitian Kuantitatif, Kualitatif, Dan R\&D. hlm 49-57.

${ }^{16}$ Ahmad Tarmizi Hasibuan and Andi Prastowo, "Konsep Pendidikan Abad 21: Kepemimpinan Dan Pengembangan Sumber Daya Manusia Sd/Mi," MAGISTRA: Media Pengembangan Ilmu Pendidikan Dasar Dan Keislaman 10, no. 1 (2019): 26-50, https://doi.org/10.31942/mgs.v10i1.2714.

17 Jarjani Usman, "Progresif Developing the Textbook of Classroom Action Research Through," Jurnal Pendidikan 11, no. 1 (2021): 1-11, https://doi.org/10.23960/jpp.v11.i1.202101. 


\section{Amiruddin S, Toni N, Khairul Anwar}

akan memperoleh pengetahuan yang lebih jauh dan mendalam secara ilmiah. ${ }^{18}$ Sampel yang digunakan adalah sampel berdasarkan pertimbangan tertentu seperti ciri-ciri populasi atau ciri-ciri yang telah diketahui sebelumnya. ${ }^{19}$

Page | 141

Sedangkan teknik pengumpulan data dilakukan dengan wawancara, observasi, dan studi pustaka. Selanjutnya keabsahan data dilakukan dengan menggunakan teknik triangulasi yaitu triangulasi sumber dan triangulasi metode. Teknik pengumpulan data dalam penelitian ini dilakukan dengan wawancara mendalam. Teknik dan instrumen dalam penelitian merupakan hal yang esensial dalam penelitian karena menyangkut keabsahan data yang akan diperoleh sebagai perwujudan hasil penelitian. ${ }^{20}$

\section{Hasil dan Pembahasan}

Kepemimpinan Kepala Sekolah dalam Penanganan Penularan Covid-19 di SD/MI Kota Medan. Dalam upaya pencegahan penularan virus Covid-19 di SD/MI Kota Medan dan pelaksanaan pembelajaran selama masa Covid-19, kepala sekolah memiliki peran vital dalam pengambilan keputusan dalam rangka melindungi keselamatan seluruh warga sekolah, baik siswa, pendidik maupun karyawan dan pelaksanaan pembelajaran tetap berjalan efektif. Kepala sekolah membuat keputusan atau kebijakan melalui rapat internal dan berkoordinasi dengan guru dan pegawai SD/MI Kota Medan mengenai kebijakan pembelajaran jarak jauh yang akan dijalankan sekolah. Kebijakan pembelajaran mengacu pada surat edaran dari Kemendikbud, surat edaran dari Gubernur Sumatera Utara, surat edaran dari Wali Kota Medan ia bersandar pada surat edaran dari PdM Kota Medan. Setelah menerima surat edaran, pihak sekolah menindaklanjuti surat edaran yang keluar dari atas dan kemudian mengeluarkan surat edaran (SE) dari kepala sekolah. Kebijakan yang dilakukan kepala

${ }^{18}$ Alfi Syahrinsi et al., "Development of Multimedia Interactive Learning of Hydrosphere Material for High School Magister Teknologi Pendidikan Universitas Sriwijaya, Palembang, Indonesia” 23, no. April (2021): 1-10, http://journal.unj.ac.id/unj/index.php/jtp/article/view/18579/10694 .

19 Mahande, Darmawan, and Malago, "Metacognitive Skill Assessment Model through the Blended Learning Management System in Vocational Education."

${ }^{20}$ Zakiyah Fawa'iedah. Mustajab, Hasan Baharun, "Adapting to Teaching and Learning During Covid-19: A Case of Islamic School's Initiative of Self-Regulated Learning.," Jurnal Pendidikan Bahasa

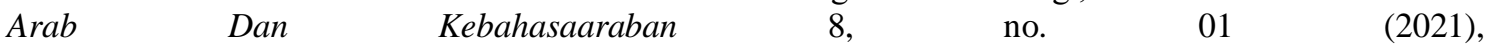
http://journal.uinjkt.ac.id/index.php/arabiyat/article/view/20689/pdf. 
sekolah SD/MI Kota Medan untuk mengatasi masalah tersebut melalui 2 cara: 1) kebijakan belajar di rumah; 2) membentuk gugus tugas covid-19.

\section{Kebijakan Belajar dari Rumah}

Sekolah sebagai penyelenggara pendidikan harus berhati-hati dan siap mengambil langkah yang tepat di masa pandemi Covid-19. Upaya-upaya sekolah dalam pencegahan penularan virus corona (Covid-19) di SD/MI Kota Medan adalah dengan mengalihkan proses belajar-mengajar yang semula dilaksanakan di sekolah dialihkan ke Pembelajaran Jarak Jauh (PJJ) atau daring dengan nomor edaran Kemendagri. ${ }^{21}$

Kemendikbud sendiri telah mengeluarkan surat terkait pembelajaran jarak jauh dan bekerja dari rumah untuk mencegah penyebaran virus Corona (COVID-19). ${ }^{22}$ Jika ada tugas yang harus dikumpulkan oleh wali siswa ke sekolah, pada saat pengumpulannya menjadi beberapa gelombang. ${ }^{23}$ Jadi, tidak ada keramaian di sekolah. ${ }^{24}$ Hal ini sesuai dengan Protokol Kesehatan Masyarakat di Tempat dan Fasilitas Umum Dalam Rangka Pencegahan dan Pengendalian Virus Corona (Covid-19), yang berisi tentang perlindungan kesehatan individu dengan menggunakan alat pelindung diri berupa masker penutup hidung dan mulut hingga dagu. ${ }^{25}$ Jika orang perlu keluar rumah atau berinteraksi dengan orang lain yang status kesehatannya tidak diketahui (yang kemungkinan besar menularkan COVID-19), bersihkan tangan secara teratur dengan mencuci tangan menggunakan sabun di bawah air mengalir atau menggunakan alkohol hand sanitizer dan menjaga kebersihan tangan. jarak 1 meter dari orang lain untuk menghindari tetesan dari orang yang sedang berbicara, batuk atau bersin, dan menghindari keramaian. ${ }^{26}$

Kepala sekolah memantau pelaksanaan pembelajaran jarak jauh melalui komunikasi online, dengan durasi seminggu sekali. Melalui proses Standard Coordinator, kepala sekolah meminta laporan mingguan pelaksanaan pembelajaran jarak jauh, kepala sekolah, dan standar proses evaluasi laporan yang disampaikan oleh masing-masing kelas. Jika ada kendala, segera

${ }^{21}$ Hasil Wawancara dengan Kepala Sekolah MIN 4 Kota Medan, pada tanggal 27 Juni 2021, pukul.08.23.

${ }^{22}$ Pendidikan dan Kebudayaan (Kemdikbud, 2020). 36962 / MPK. A/HK/202. 12.00 .

${ }^{23}$ Hasil Wawancara dengan Guru Kelas I MIN 4 Kota Medan, pada Tanggal 31 Juni 2021, pukul

${ }^{24}$ Hasil Wawancara dengan Guru Kelas II SDN 060855, pada tanggal 02 Juli 2021, Pukul.08.12. 2020.

25 “Keputusan Menteri Kesehatan Republik Indonesia [29] Nomor Hk.01.07/Menkes/382/2020,"

${ }^{26}$ Hasil Wawancara dengan Kepala Sekolah 


\section{Amiruddin S, Toni N, Khairul Anwar}

komunikasikan dengan kelas agar proses pembelajaran jarak jauh dapat berjalan dengan baik. Sekolah juga tidak melaksanakan Ujian Akhir Sekolah Daerah (UASDA) mengikuti surat edaran Kemendikbud Nomor 4 tahun 2020 tentang Penyelenggaraan Pendidikan Dalam

Keadaan Darurat Virus Corona (COVID-19). ${ }^{27}$

\section{Membentuk Gugus Tugas Covid 19}

Kepala sekolah membentuk satuan tugas Covid-19 tingkat sekolah yang terdiri dari guru, karyawan, dan masyarakat sekitar. ${ }^{28}$ Kepala sekolah bersama satgas membuat aturan kepada seluruh warga sekolah untuk selalu mematuhi protokol kesehatan yaitu dengan mengecek suhu tubuh, mencuci tangan dengan sabun dan air mengalir, memakai masker, menjaga jarak dengan orang lain minimal 1 meter. ${ }^{29}$ Sekolah melakukan pengadaan sarana prasarana yang diperlukan untuk melaksanakan protokol kesehatan berupa penambahan wastafel, thermogun, sabun cuci tangan, tisu, cairan desinfektan, penyemprot desinfektan, masker, hand sanitizer, dan face shield. ${ }^{30}$

Secara berkala, sekolah melakukan penyemprotan cairan desinfektan ke seluruh lingkungan sekolah, termasuk seluruh ruang kelas. Kepala sekolah memantau kesehatan seluruh warga sekolah setiap minggu, berkomunikasi dengan mereka melalui grup WhatsApp. ${ }^{31}$ Selain itu, kepala sekolah membuat kebijakan pelaksanaan tugas guru dan tenaga kependidikan di masa pandemi dengan sistem shift atau piket bergantian, ${ }^{32}$ maksimal $50 \%$ kehadiran seluruh guru dan tenaga kependidikan setiap hari, mulai pukul 08.00-13.00. ${ }^{33}$ Jadwal piket diatur sesuai dengan bagian kepegawaian sekolah.

Kepemimpinan sangat dibutuhkan kepala sekolah sebagai pelaku dalam dunia pendidikan. Kepala sekolah adalah pemimpin sekaligus manajer. Sebagai pemimpin suatu

${ }^{27}$ Hasil Observasi di SDN 060855, Pada tanggal 07 Juni 2021, pukul.08.21.

${ }^{28}$ Hasil Observasi dan Wawancara dengan Kepala Sekolah MIN 4 Kota Medan, pada tanggal 09 Juli 2021, pukul.08.36.

${ }^{29}$ Hasil Observasi di MIN 4 Kota Medan, pada tanggal 09 Juli 2021, pukul.07.06.

${ }^{30}$ Hasil Wawancara dan Observasi dengan Kepala Sekolah SDN 060855, Pada tanggal 10 Juli 2021, pukul.09.03.

31 Hasil Wawancara dengan Guru Kelas III MIN 4 Kota Medan, pada tanggal 11 Juli 2021, pukul.08.04.

${ }^{32}$ Hasil Observasi di SDN 060855, Pada tanggal 13 Juli 2021, pukul. 07.47.

33 Hasil Wawancara dan Observasi di MIN 4 Kota Medan, pada tanggal 15 Juli 2021, pukul.09.04. 
lembaga, kepala sekolah harus memiliki jiwa kepemimpinan yang baik dalam menjalankan tugasnya sebagai seorang pemimpin. ${ }^{34}$ Kepemimpinan kepala sekolah dituntut untuk mulai mendapatkan pekerjaan sebagai kepala sekolah. Kepemimpinan kepala sekolah sangat berperan dalam keberhasilan pelaksanaan program yang telah direncanakan untuk mencapai tujuan pendidikan di sekolah tersebut. ${ }^{35}$ Ketika melaksanakan program yang sesuai dengan rencana awal, kualitas kepemimpinan kepala sekolah juga diperlukan dalam pengambilan keputusan di saat darurat dan insidental. Kepala sekolah dalam mengambil keputusan termasuk dalam kompetensi manajerial. ${ }^{36}$

Manajer adalah orang yang melakukan sesuatu dengan benar (the person who do things right), tugas manajer adalah merencanakan, mengorganisasikan, mengorganisir, mengkoordinasikan dan mengendalikan untuk mencapai tujuan yang telah ditentukan. Sebagai manajer, tugas kepala sekolah adalah merencanakan, mengorganisasikan, mengorganisasikan, mengkoordinasikan, dan mengendalikan untuk mencapai tujuan yang telah ditetapkan dengan menjalankan fungsi manajemen.

\section{Bekerjasama dan Menjalin Komunikasi dalam Memecahkan Masalah}

Sebelum mengambil keputusan, kepala sekolah mempertimbangkan situasi dan kondisi yang terjadi. ${ }^{37}$ Dalam hubungan ini, keputusan kepala sekolah (manajer) adalah cara bertindak yang dipilih oleh manajer sebagai langkah paling signifikan untuk memecahkan suatu masalah atau mencapai suatu tujuan. Dalam hal ini, keputusan kepala sekolah (manajer)

\footnotetext{
${ }^{34}$ Trimurtini Trimurtini et al., "Development of Mind Mapping-Based Comics to Improve Math Learning Outcomes," Premiere Educandum: Jurnal Pendidikan Dasar Dan Pembelajaran 11, no. 1 (2021): 15, https://doi.org/10.25273/pe.v11i1.7817.

${ }^{35}$ Mahande, Darmawan, and Malago, "Metacognitive Skill Assessment Model through the Blended Learning Management System in Vocational Education." Ridwan Daud Mahamde. Fitrah Asma Darmawan. Jasruddin Daud Malago. Metacognitive skill assessment model through the blended learning management system in vocational education. Junral Pendidikan Vokasi . Volume 11, No. 1, 2021. https://journal.uny.ac.id/index.php/jpv/article/view/36912/15792

${ }^{36}$ Purnama Sari and Sutarto., "Implementation of Multicultural Islamic Education Values In the Tradition of the Feast on Marriage in the Barumanis Village.," Jurnal Penelitian Pendidikan Agama Dan Keagamaan. $19, \quad$ no. 01 http://www.jurnaledukasikemenag.org/index.php/edukasi/article/view/829/pdf.

37 Hasil Wawancara dengan Kepala Sekolah SDN 060855, pada tanggal 17 Juli 2021, pukul. 07.35.
} 


\section{Amiruddin S, Toni N, Khairul Anwar}

adalah cara bertindak yang dipilih oleh manajer sebagai langkah paling signifikan untuk memecahkan masalah atau mencapai tujuan. ${ }^{38}$

Pengambilan keputusan, menurut adalah mengusulkan ketika manajer menggunakan Page | 145 urutan empat langkah yang rasional ketika membuat keputusan. Pertama, mengidentifikasi masalah. Kedua, menghasilkan alternatif. Ketiga, memilih solusi, dan Keempat, mengimplementasikan dan mengevaluasi solusi. ${ }^{39}$ Keputusan adalah untuk menanggapi masalah. Masalah dapat bervariasi dalam minat mereka, mulai dari mencari tahu pekerjaan mana yang harus diterima setelah lulus. ${ }^{40}$

Pengambilan keputusan sangat penting bagi kepala sekolah, karena proses pengambilan keputusan memiliki peran dalam menggerakkan, berkomunikasi, dan memotivasi bawahannya. Kepala sekolah harus memiliki keterampilan mengambil keputusan secara cepat, tepat, efektif, dan efisien untuk mencapai tujuan pendidikan. ${ }^{41}$ Fungsi manajemen dapat dibagi menjadi empat bagian: perencanaan, pengorganisasian, penggerak, dan pengendalian. ${ }^{42}$ Ini mengikuti tugas kepala sekolah selama pelaksanaan Pembelajaran Jarak Jauh (PJJ) di masa pandemi. Dalam pelaksanaan pembelajaran jarak jauh, kepala sekolah merencanakan program PJJ, mengorganisir guru dan pegawai dalam pelatihan LFH, melakukan pembelajaran jarak jauh bersama seluruh guru, serta memantau dan mengevaluasi pelaksanaan PJJ di masa pandemi Covid-19. ${ }^{43}$

Saat ini Indonesia sedang menghadapi wabah virus Covid-19 yang telah menjangkiti beberapa orang. Beberapa daerah telah menjadi zona merah penularan virus ini. Setiap hari jumlah orang Indonesia yang dinyatakan positif terinfeksi semakin meningkat, dan

${ }^{38}$ Hasil Wawancara dengan Kepala Sekolah MIN 4 Kota Medan, pada Tanggal 18 Juli 2021, pukul 09.12.

${ }^{39}$ I Dewa Putu Subamia et al., "O1 Treatmen O2 Postest," Jurnal Pendidikan Kimia Indonesia 5, no. 1 (2021): 1-8, https://ejournal.undiksha.ac.id/index.php/JPK/index.

40 Mohamad Ridhuan Abdullah et al., "Contrasts Between Moral and Islamic Religious Education: Dilemmas and Prospects," Jurnal Pendidikan Islam 10, no. 1 (2021): 1-22, https://doi.org/10.14421/jpi.2021.101.1-22.

${ }^{41}$ Hasil Wawancara dengan Kepala Sekolah SDN 060855, pada tanggal 17 Juli 2021, pukul. 07.39 .

${ }^{42}$ Hasibuan and Prastowo, "Konsep Pendidikan Abad 21: Kepemimpinan Dan Pengembangan Sumber Daya Manusia Sd/Mi.”

43 Hasil Observasi dan Dokumentasi di MIN 4 Kota Medan, Pada tanggal 21 Juli 2021, pukul.10.12. 
peningkatannya semakin meningkat. Hal tersebut menjadi pendorong hampir seluruh wilayah Indonesia menghilangkan pembelajaran tatap muka tidak terkecuali pada jenjang SD/MI untuk sementara waktu. Termasuk Kota Medan sebagai Kota terpadat juga terkena imbasnya. ${ }^{44}$

Proposisi di atas mengakibatkan sekolah menghilangkan pembelajaran tatap muka untuk mengantisipasi penularan virus Covid-19 dengan meminimalisir kontak langsung antar warga sekolah. Karena dengan kebijakan dan upaya yang tepat dapat berdampak baik bagi keberlangsungan lembaga yang dipimpinnya dan sebaliknya. ${ }^{45}$ Jika kepala sekolah tidak memiliki kualitas kepemimpinan yang baik dalam mengambil kebijakan darurat, maka akan berakibat fatal bagi kondisi lembaganya. ${ }^{46}$

Kepala sekolah dalam keadaan darurat, selalu berpikir dengan tenang namun waspada. Pikiran yang tenang akan memudahkan dalam mencari solusi dari suatu masalah. Sebagai pemimpin dalam suatu lembaga, kepala sekolah harus memperhatikan beberapa hal sebagai acuan atau pertimbangan dalam pengambilan kebijakan. Sekolah memiliki hubungan struktural dengan lembaga lain di dalamnya, sehingga pengambilan keputusan harus mempertimbangkan rekomendasi lembaga di atasnya, misalnya Dinas Pendidikan atau Yayasannya. Kepala sekolah harus mempertimbangkan kondisi sekolah, kondisi guru, dan kondisi siswa agar pengambilan kebijakan dapat bermanfaat bagi semua. ${ }^{47}$

Kepala sekolah berkomunikasi dengan baik untuk menyampaikan kebijakan dinas kepada orang tua agar dapat diterima, dimaafkan, dan dilaksanakan arahannya. Selain menyampaikan kebijakan terkait siswa, kepala sekolah juga harus melakukan tindakan preventif secara mandiri, seperti 1) Anjurkan kepada seluruh warga sekolah untuk selalu minum vitamin $\mathrm{C}$, berolahraga secara teratur, mencuci tangan dengan benar menggunakan sabun dan air mengalir, 3) Melakukan social dan physical distancing, menghindari tempat

\footnotetext{
${ }^{44}$ Tutuk Ningsih, Novan Ardy Wiyani. Theological Values Internalization in Central Learning Management at Kindergarten. Edukasia Islamika:Jurnal Pendidikan Islam, Volume 6 No 1, 2021, hal.96. https://doi.org/10.28918/jei.v6i1.3680.

${ }^{45}$ Hasil Wawancara dengan Guru Kelas IV SDN 060855, pada tanggal 17 Juli 2021, pukul 10.23 . pukul.11.42.

${ }^{46}$ Hasil Wawancara dengan Guru Kelas V MIN 4 Kota Medan, pada tanggal 16 Juli 2021,

${ }^{47} \mathrm{~S}$ Kusairi et al., "E- Formative Assessment Integration in Collaborative Inquiry: A Strategy to Enhance Students ' Conceptual Understanding in Static Fluid Concepts," no. June (2021), https://doi.org/10.15294/jpfi.v17i1.23969.
} 


\section{Amiruddin S, Toni N, Khairul Anwar}

keramaian, menghindari kontak langsung dengan orang lain seperti berjabat tangan, berpelukan, dll, serta menghindari penggunaan kendaraan umum, 4) Melakukan penyemprotan lingkungan sekolah dengan cairan desinfektan secara berkala, 5) Menyediakan hand sanitizer dan sabun tangan di setiap wastafel dan toilet. 6) Menggali informasi dari berbagai sumber terkait virus Covid-19, 7) Menciptakan suasana tenang bagi seluruh warga sekolah, 8) Melakukan komunikasi yang baik dengan semua pihak, baik instansi, yayasan, masyarakat sekitar, komite sekolah, maupun orang tua siswa untuk mengkomunikasikan halhal penting terkait penanganan penularan Covid-19 yang memerlukan penanganan segera serta memerlukan kerjasama dan koordinasi semua pihak.

Dengan diterapkannya pembelajaran jarak jauh, ada beberapa langkah yang dilakukan sekolah, yaitu: Penyusunan kurikulum suplemen masa pandemi/darurat covid-19, pemetaan kemampuan pengetahuan dan pemanfaatan teknologi, pemenuhan pengetahuan dan kemampuan guru tentang pembelajaran jarak jauh. teknologi, pemenuhan pemahaman guru terhadap materi, melibatkan orang tua dan masyarakat dalam proses pembelajaran jarak jauh, orang tua dan masyarakat harus mengambil porsi dan posisi yang optimal ketika pembelajaran di sekolah tidak dapat dilaksanakan, dengan kemampuan kepala sekolah dalam mengkomunikasikan pesan dengan baik, membangun kolegialitas antara guru dan karyawan serta kepada orang tua, untuk dapat bersama-sama melaksanakan kebijakan sebagai penentu keberhasilan visi misi penanggulangan penularan virus covid-19 di tingkat satuan pendidikan.

\section{Simpulan}

Kepemimpinan Kepala Sekolah di SD Negeri 060855 dan MIN 4 Kota Medan dalam pencegahan Covid 19 menerapkan 3 kebijakan. Pertama, kepala sekolah memberikan kebijakan belajar dari rumah. Kedua, membentuk tim Gugus Tugas. Ketiga, bekerjasama dan menjalin komunikasi dalam memecahkan masalah. Namun peneliti memberikan saran kepada kepala sekolah SD/MI Kota Medan, Yaitu, Pertama, untuk menganjurkan kepada seluruh warga sekolah untuk selalu minum vitamin $\mathrm{C}$, berolahraga secara teratur, mencuci tangan dengan benar menggunakan sabun dan air mengalir. Kedua, Melakukan sosial dan physical distancing, menghindari tempat keramaian, menghindari kontak langsung dengan orang lain seperti berjabat tangan, berpelukan, dll, serta menghindari penggunaan kendaraan umum. Ketiga, Melakukan penyemprotan lingkungan sekolah dengan cairan desinfektan 
Kepemimpinan Kepala Sekolah...

secara berkala. Keempat, Menyediakan hand sanitizer dan sabun tangan di setiap wastafel dan toilet. Kelima, Menggali informasi dari berbagai sumber terkait virus Covid-19. Keenam, Menciptakan suasana tenang bagi seluruh warga sekolah. 


\section{DAFTAR PUSTAKA}

Abdullah, Mohamad Ridhuan, Tanzima Sultana, Azianura Hani Shaari, and Nurliana Dalila Page | 149 Binti Shaari. "Contrasts Between Moral and Islamic Religious Education: Dilemmas and Prospects." Jurnal Pendidikan Islam 10, no. 1 (2021): 1-22. https://doi.org/10.14421/jpi.2021.101.1-22.

Brown, Malcolm, Mark Mccormack, Jamie Reeves, D Christopher Brooks, Susan Grajek, Maha Bali, Stephanie Bulger, et al. "Framework_Guide_V1_002_Harward." Journal of Professional Capital and Community 28, no. $2-$ (2020): 2340-50. http://oro.open.ac.uk/59302/7/Thesis Final Papathoma_03.03.2019.pdfhttp://www.scielo.org.pe/pdf/pyr/v7n2/a21v7n2.pdf.

Furhan, A. Pengantar Metode Penelitian Kualitatif. Surabaya: Usaha Nasional, n.d.

Hasibuan, Ahmad Tarmizi, and Andi Prastowo. "Konsep Pendidikan Abad 21: Kepemimpinan Dan Pengembangan Sumber Daya Manusia Sd/Mi." MAGISTRA: Media Pengembangan Ilmu Pendidikan Dasar Dan Keislaman 10, no. 1 (2019): 26-50. https://doi.org/10.31942/mgs.v10i1.2714.

Hewi, La, and Linda Asnawati. "Strategi Pendidik Anak Usia Dini Era Covid-19 Dalam Menumbuhkan Kemampuan Berfikir Logis.” Jurnal Obsesi : Jurnal Pendidikan Anak Usia Dini 5, no. 1 (2020): 158. https://doi.org/10.31004/obsesi.v5i1.530.

Kaniawati, Ida, Agus Danawan, Iyon Suyana, Achmad Samsudin, and Endi Suhendi. "Implementation of Interactive Conceptual Instruction (ICI) With Computer Simulation: Impact of Students' Misconceptions on Momentum and Impulse Material." Jurnal Ilmiah Pendidikan Fisika Al-Biruni 10, no. 1 (2021): 1-17. https://doi.org/10.24042/jipfalbiruni.v10i1.8375.

Karim, Bisyri Abdul. "Pendidikan Perguruan Tinggi Era 4.0 Dalam Pandemi Covid-19 (Refleksi Sosiologis).” Education and Learning Journal 1, no. 2 (2020): 102. https://doi.org/10.33096/eljour.v1i2.54.

"Keputusan Menteri Kesehatan Republik Indonesia [29] Nomor Hk.01.07/Menkes/382/2020,”2020.

Kusairi, S, H A Hardiyana, P Suwasono, A Suryadi, and Y Afrieni. "E- Formative Assessment Integration in Collaborative Inquiry: A Strategy to Enhance Students , Conceptual Understanding in Static Fluid Concepts," no. June (2021). https://doi.org/10.15294/jpfi.v17i1.23969.

Lexy. J, Meleong. Metode Penelitian Kualitatif. Bandung: PT Remaja Rosdakarya, 2019.

Mahande, Ridwan Daud, Fitrah Asma Darmawan, and Jasruddin Daud Malago. "Metacognitive Skill Assessment Model through the Blended Learning Management 
System in Vocational Education.” Jurnal Pendidikan Vokasi 11, no. 1 (2021): 1-13. https://doi.org/10.21831/jpv.v11i1.36912.

Mustajab, Hasan Baharun, Zakiyah Fawa'iedah. "Adapting to Teaching and Learning During Covid-19: A Case of Islamic School's Initiative of Self-Regulated Learning." Jurnal Pendidikan Bahasa Arab Dan Kebahasaaraban 8, no. 01 (2021). http://journal.uinjkt.ac.id/index.php/arabiyat/article/view/20689/pdf.

Muti'ah, Ulin Nuskhi. ", Teaching Collaborations in Elementary Schools: Teacher's Understanding, Strategies, and Obstacles." Ta'dib: JURNAL PENDIDIKAN GURU MI 8, no. 1 (2021): 1-15. http://syekhnurjati.ac.id/jurnal/index.php/ibtida.

Santanu, Hurry Mega Insani Lilik Kustiyah Cesilia Meti Dwiriani Ayu Mutiara. "Nutrition Education on Sedentary Activity for Adolescent." Jurnal Pendidikan Jasmani Dan $\begin{array}{lllll}\text { Olahraga. } & 06, & \text { no. } & 01 & \text { (2021): }\end{array}$ https://ejournal.upi.edu/index.php/penjas/article/view/6-1-01.

Sari, Purnama, and Sutarto. "Implementation of Multicultural Islamic Education Values In the Tradition of the Feast on Marriage in the Barumanis Village." Jurnal Penelitian Pendidikan Agama Dan Keagamaan. 19, no. 01 (2021). http://www.jurnaledukasikemenag.org/index.php/edukasi/article/view/829/pdf.

Sri Wahyuningtyas Leonard Natalia Tri Astuti. "Developing MATMINO (Domino Mathematics) Learning Media in Grade 7 Algebra Material." Jurnal Ilmiah Pendidikan $\begin{array}{lllll}\text { MIPA } & 11, & & & \end{array}$ https://journal.lppmunindra.ac.id/index.php/Formatif/index.

Subamia, I Dewa Putu, I Gusti Ayu, Nyoman Sri, and Ni Nyoman Widiasih. "O1 Treatmen O2 Postest." Jurnal Pendidikan Kimia Indonesia 5, no. 1 (2021): 1-8. https://ejournal.undiksha.ac.id/index.php/JPK/index.

Sugiyono. Metode Penelitian Kuantitatif, Kualitatif, Dan R\&D. Bandung: Alfabeta, 2014.

Susilowati, Wandika Wita, and Suyatno Suyatno. "Teacher Competence in Implementing Higher-Order Thinking Skills Oriented Learning in Elementary Schools." Premiere Educandum: Jurnal Pendidikan Dasar Dan Pembelajaran 11, no. 1 (2021): 1. https://doi.org/10.25273/pe.v11i1.7762.

Syahrinsi, Alfi, L R Retno Susanti, Sardianto Markos Siahaan, and Mts Negeri Banyuasin. "Development of Multimedia Interactive Learning of Hydrosphere Material for High School Magister Teknologi Pendidikan Universitas Sriwijaya , Palembang , Indonesia” 23, no. April (2021): http://journal.unj.ac.id/unj/index.php/jtp/article/view/18579/10694 .

Trimurtini, Trimurtini, Mira Amalia Setyani, Elok Fariha Sari, and Nursiwi Nugraheni. "Development of Mind Mapping-Based Comics to Improve Math Learning Outcomes." Premiere Educandum: Jurnal Pendidikan Dasar Dan Pembelajaran 11, no. 1 (2021): 15. https://doi.org/10.25273/pe.v11i1.7817. 


\section{Amiruddin S, Toni N, Khairul Anwar}

Usman, Jarjani. "Progresif Developing the Textbook of Classroom Action Research Through." Jurnal Pendidikan 11, no. 1 (2021): 1-11. https://doi.org/10.23960/jpp.v11.i1.202101.

Page | 151 